\title{
ROLE OF LAW IN CONSTRUCTION AND DEVELOPMENT OF SMALL SCALE INDUSTRIES THROUGH NORMATIVE PERSPECTIVE
}

\author{
Endang Sutrisno \\ Magister of Legal Studies Programme \\ Swadaya Gunung Jati University of Cirebon \\ E-mail: endangsutrisno94@gmail.com
}

\begin{abstract}
The presence of law has become an absolute prerequisite that must exist in the dynamics of civil society. It is to achieve justice, certainty, and expediency, so the works of it will not be separated from such a noble mission. On the other side, the law is likely inseparable from the fields of metajuridical, including economics. The expectations of the interference of law into economy, makes the existence of justice for the business players can be realized through the enacted product legislation. Regulations concerning investments and partnerships have the intent to build self-reliance and empowerment for small industry players so as to compete in the era of economic globalization. Laws employed as the instrument of social change to strengthen the capitalization of small industry and business empowerment through the training and development of small industries, as normatively mandated by law.
\end{abstract}

Key words: progressive law, normative dimention, small industry

\begin{abstract}
Abstrak
Kehadiran hukum menjadi prasyarat mutlak yang harus ada dalam dinamika kehidupan masyarakat. Hukum hadir untuk mencapai tujuan keadilan, kepastian dan kemanfaatan, sehingga aktivitas bekerjanya hukum tidaklah akan terlepas dari misi luhur tersebut. Pada sisi lain hukum-pun tidak mungkin dipisahkan dari bidang-bidang meta yuridis, termasuk ekonomi. Harapan masuknya hukum ke tataran ekonomi, menjadikan eksistensi keadilan untuk pelaku-pelaku bisnis dapat diwujudkan khususnya melalui produk perundang-undangan yang diberlakukan. Regulasi menyangkut investasi dan kemitraan mengandung maksud membangun kemandirian dan pemberdayaan untuk pelaku industri kecil sehingga mampu bersaing di era globalisasi ekonomi. Hukum dijadikan sarana untuk melakukan perubahan sosial, yang berakibat pada aspek penguatan permodalan industri kecil serta pemberdayaan usaha melalui pembinaan dan pengembangan industri kecil, sebagaimana yang diamanatkan oleh undang-undang secara normatif.
\end{abstract}

Kata Kunci : hukum progresif, dimensi normatif, industri kecil

\section{Introduction}

The law has a very important role in terms of the legal relations of the parties nor the legality of economic activity itself, which means that business activity should be in good-setting so that inequality and injustice does not happen. ${ }^{1}$ The function of the law on the one hand can be used as a means to change the society in order to become better and on the other hand to maintain the pattern of existing com-

Sri Redjeki Hartono, 2007, Orientasi Ke Arah Pengelolaan Investasi (Sebuah Landasan Pemikiran Awal), Bandar Lampung: Lampung University, page 2. munities as well as validating the changes that have occurred in the past. ${ }^{2}$ In the end there are 5 (five) prerequisite conditions in order for the legal support of economic development which can be described in figure 1 .

Based on Figure 1 above, this illustrates that the legal system essentially sought to have the task to keep existing interests in the growth of community development that competes each other, so that it is required factors, which are stability through a secure state of attempt-

Satjipto Rahardjo, 2010, Ilmu Hukum, Bandung: Alumni, page 5-6. 
ed law can play a role in the motion dynamics of community development, the existence of condition that is able to predict the changes occured, the existence of values of honesty in development activities, education aspect and ability of the legal profession that are able to anticipate problems arising in consequence of the development changes. Development of Indonesia's legal system since the time of colonial up to Romli Atmasasmita currently, distinguish in 4 (four) of the law models; first, highly repressive collonial law model; second, development law model; third, progressive law model; and fourth, integrative law model. ${ }^{3}$

Figure 1 : Five Prerequisite of Legal Conditions Supporting Economic Development

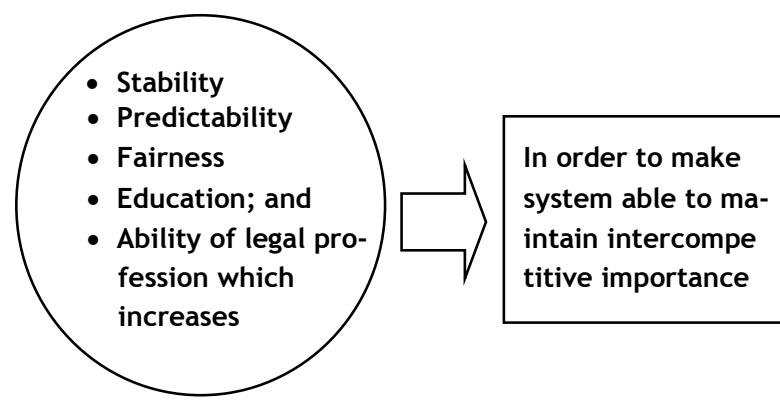

Related to efforts actualizing the effective legal system need realignment of institutional law supported by the quality of the human resources and legal awareness of society and culture that continue to rise, along with the renewal of legal materials are structured harmoniously without conflict and overlapping and law continuously is updated in accordance with the demands of development needs. ${ }^{4}$

It is necessary to realize that legal justice is required to create an active role of the various parties ranging from the establishment of a legal product to enforcement of legal products. ${ }^{5}$ The law has a sovereignty based on peo-

3 Romli Atmasasmita, 'Tiga Paradigma Hukum dalam Pembangunan Nasional", Jurnal Hukum Prioris, Vol. 3 No. 1 Year 2012, Jakarta: Law Faculty, Trisakti University, page 5 .

4 Bahria Prentha, "Filsafat Hukum dan Nilai-Nilai Pancasila”, Jurnal Ilmiah Kebijakan Hukum, Vol. 5 No. 2 August 2011, Jakarta: Pusat Pengkajian dan Pengembangan Kebijakan Kementerian Hukum dan HAM RI, page 177.

5 Yunus Bureni, “Moralitas Pembentukan Peraturan Daerah dalam Upaya Mencapai Keadilan Substantif (Morality Formation of Local Regulations in An Effort to Ensure ple sovereignty, can be made a "hypothesis" 6 that the sovereignty of the law was not intended solely for the benefit of the law itself, but must rather be addressed and stood for community interests. Normative provisions concerning small businesses, making the law should really be showing face alignments on a small marginalized community interests. This became the key to the direction of the development of the law that is most essential goals of law existence in the life of the community. It is so fully realized that so far law development in this country tends to move in the artificial space and without direction. ${ }^{7}$ Indonesia today is faced with a very "unique" problem of law performance regarding the formal truth treated as the most dominant consideration of legal decision embracing reine Rechtslehre Kelsenian's way of thinking. An approach that is still in further discussion through a more holistic alternative paradigm. ${ }^{8}$ The teaching of legal positivism which is monistic, where it only admits one kind of Justice, that justice is born from positive law. ${ }^{9}$

The development of small industries in fulfilling their needs, especially in terms of overcoming the limitations, the partnership became the only option that needs to be done by small industries with medium and large industries. In partnership, there is cooperation between the major industry and medium scale in-

Substantive Justice)", Jurnal Legislasi Indonesia, Vol.10 No.2 June 2013, Jakarta: Direktorat Jenderal Peraturan Perundang-undangan Kementerian Hukum dan HAM RI, page 125.

6 Bambang Widjojanto, "Negara Hukum, Korupsi dan Hak Asasi Manusia: Suatu Kajian Awal", Jurnal Hukum Prioris, Vol. 3 No.1 Year 2012, Jakarta: Law Faculty, Trisakti University, page 30.

7 Dayanto, "Rekonstruksi Paradigma Pembangunan Negara Hukum Indonesia Berbasis Pancasila", Jurnal Dinamika Hukum, Vol. 13 No. 3 September 2013, Purwokerto: Law Faculty Jenderal Soedirman University, page 498.

8 Endang Sutrisno, "Tracing the Performance of Law in Indonesia (A Perspective of Thomas Kuhn's “Normal Science", Journal of Law, Policy and Globalization, International Institute for Science, Technology \& Education Accelerating Global Knowledge Creation and Sharing, page 126.

9 Ibnu Artadi, “Dekonstruksi Pemahaman Penyelesaian Sengketa Bisnis (Ekonomi dan Keuangan) Beraspek Pidana melalui Prosedur Perdamaian: Menuju Proses PeradiIan Pidana Rekonsiliatif”, Jurnal Hukum Responsif, Vol. 1, No. 1 Year 2011, Cirebon: Law Faculty, Swadaya Gunung Jati University, page 33-34. 
dustry and small industry, this can be form of home industry, basically mutual benefit for both parties who perform such cooperation. This reason is based on a logical consideration of economic development being one way in prospering community, in the economic development required friendly bureaucracy towards capital investment. ${ }^{10}$

Law No. 25 of 2007 about Capital Investment, in Chapter VIII: Development Capital Investment for Micro, Small, Medium Scale Enterprises and Cooperatives Article 13 paragraph (2) mentions that the Government does the asistance and development of micro, small, medium scale enterprises and cooperatives through partnership programs, improvement of competitiveness, giving of the encouragement of innovation and market expansion, as well as the dissemina-tion of the information widely. This regulation clearly became quite good driving factor as a juridical foundation in the basis of the latest arrangement of a partnership, besides as set in Government Regulation No. 44 in 1997 about Partnership.

The problem can be discuss in this article are: first, how does the normative landscape set in relation to the contract of the partnership done towards parties as construction and development of small industries in perspective of capital investment?, and second, how does the partnership patterns conducted by the parties in the framework of the construction and development of human resources in relation to Law No. 25 of 2007 and Government Regulation No. 44 in 1997 about the Partnership?

\section{Small, Medium and Large Business Partners- hipps in Normative Level Dimension.}

The notion of partnership according to the Act No.44 of 1997 i.e. cooperation effort between small business and medium-sized business or with great effort by observing the principle of mutual need, mtually reinforcing and mutually benefecial. The law in the form of the

10 Haris Budiman \& Suwari Akhmaddhian, "Implementasi Reformasi Birokrasi Bidang Perizinan Penanaman Modal di Kabupaten Kuningan", Jurnal Ilmu Hukum Unifikasi, Vol. 1, No. 1 October 2013, Kuningan: Law Faculty, Kuningan University, page 2. legislation, product policy should be understood in its realization in all jurisdictions-and in all steps is supposed to be an entity that is authentic. The definition of authentic here is meant more as an entity that genuine compliance with the existence, based on Gustav Radbruch, the nature's existence of law can be simplified into several goals to be achieved i.e. justice, legal certainty and benefit ${ }^{11}$. It aims to achieve the target as the ideals of Justice as a manifestation of popular sovereignty. Justice is something abstract that is in sollen world grown in human's biological skepticism, but could not be overlooked that everyone crave justice. In the science of law, justice is the idea and law purpose but literally, justice could not be defined by science of law; thus, justice should be examined with theoretic and philosophy perspective. ${ }^{12}$

The partnership concept formulated in article 26 The Govement Regulation No.44 in 1997 about partnership as follows. First, medium and large business to have partnership relations with small business either have or do not have a business relationship. Second, implementation of the partnership referred to in subsection strived towards the attainment of business relations. Third, partnerships implemented with an accompanying coaching and development in one or more fields and production managers, marketing, human resources, capital and technology. Fourth, in the exercise of the relationship of the two sides have equal legal position.

Various studies in developing of small businesses in Indonesia show that small businesses experiencing weakness in almost every aspects,

11 Yudi Kristiana, "Ketika Hukum Tidak Lagi Otentik", Jurnal Hukum Supremasi, Vol. IV, No. 1 October 2010March 2011, Jakarta: Pusat Studi Hukum Bisnis, Law Faculty, Sahid University, page 741-742. Read also Endang Sutrisno, "Implementasi Pengelolaan Sumber Daya Pesisir Berbasis Pengelolaan Wilayah Pesisir Secara Terpadu untuk Kesejahteraan Nelayan (Studi di Perdesaan Nelayan Cangkol Kelurahan Lemahwungkuk Kecamatan Lemahwungkuk Kota Cirebon)", Jurnal Dinamika Hukum, Vol. 14, No. 1 January 2014. Purwokerto: Law Faculty, Jenderal Soedirman University, page 9.

12 Bahder Johan Nasution, "Kajian Filosofis tentang Konsep Keadilan dari Pemikiran Klasik sampai Pemikiran Modern", Jurnal Hukum Yustisia, 89 eds May-August 2014, Tahun XXIII, page 119. 
such as the providing of raw materials, production techniques, capital management, marketing and human resources. In line with expectations for small businesses to obtain the positive benefits of the ongoing globalization of world trade, there are at least two major dimensions that should be done by the government.

The first dimension, related to the business of preparing the company's internal condition of small businesses to be ready to facing the open market opportunities. The second dimension, which must be prepared by the government lies in the macro framework of the creation of the climate of healthy competition between small businesses and large enterprises in the form of competition policies. It will surely have an impact on the reduction of the facility that is much enjoyed by big business. Competition policy itself does not always mean that small businesses need protection from the government all the time. Thing which needed is the government's drive to large companies, who enjoyed the facility, in order to drain the subsidy to small busines-ses while having a share (subcontracting) whch in turn removes the subsidy after small businesses powerful and efficient.

The emergence of the globalization of world trade can be used as an opportunity for the small businesses in Indonesia, if the government and the small business willing to jointly prepare themselves through economic policy that taken. From the Government, the determination of boundaries and criteria of the Small Business that are similar and comprehensive for all agencies in Indonesia coupled with the formulation of competition policy is an action that is very urgent to be realized, meanwhile, small businesses themselves need to continue to improve and overcome the internal problem of the company for the entire aspects that become an obstacle for small businesses for example raw materials, production techniques, management, financing, marketing and human resources. It is the role of government that can solve all the problems of small businesses with the issuance of Government Regulation 44 of 1997 concerning the Partnership.
Competitive conditions will be more stringent in line with the development of the worId economy, and the partnership became one of the keys to deal with it. The era of ASEAN Economic Community (AEC) is formed of a single market in Southeast Asia. MEA aims to increasing the competition and improving the quality of ASEAN citizens to be able to have competitiveness with people outside ASEAN, it could be imagine what will happen when the current MEA is already running. Increasing competition demands products competition both goods and services, a threat that is counterproductive if the state in this case the government does not provide guarantees and protection as well as referrals or restriction in the constitution on the implementation of MEAs ${ }^{13}$.

Partnership in terms of large enterprises and medium-sized enterprises or small businesses that take place within the framework of sub-contracts to produce goods or services. Businesses large or medium-sized businesses donated. First, the opportunity to spend a portion of the production and or components. Second, the widest possible opportunity in obtaining raw materials it produces an ongoing basis with the amount and reasonable price. Third, guidance and technical capabilities of production or management. Fourth, acquisition, control and improvement of the necessary technology. Fiveth, defrayal.

Small and medium enterprises in this regard has been proving resilient to the current economic crisis, other things that can be explained that the debts incurred are debts conglomerate that jammed does not have the ability to pay, while for small and medium enterprises this issue does not occur so which should be given more pressure is increased professionalism of small and medium-sized enterprises, which in turn is expected to serve as the backbone of the country's economy as well as in Article 33 of the Republic of Indonesia Constitution Year 1945 mandates. Partnership as a form to face the competition because the context of

13 Oly Viana Agustine, "Konstitusi Ekonomi menghadapi Masyarakat Ekonomi ASEAN (MEA) Tahun 2015”, Jurnal Konstitusi, Volume 11 No. 4, December 2014, page 778. 
an economic competition has three benefits, the first is the economic, technological and trade aspects. ${ }^{14}$ Essentially, the partnership emphasizing into to three basic principles which must be implemented that require mutual, mutually reinforcing and mutually beneficial to the parties who enter into a contract of partner-ship as outlined in the normative order that the Act No. 25 of 2007 and Constitution No. 44 of 1997.

Partnership Pattern in Perspective of Act No. 25 of 2007 and No. 44 of 1997 about Partnership.

The presence of investment, especially for foreign investments give the effect of positive and negative aspects. Positive aspects are those it helps to increase the rate of economic growth through the management of economic resources, providing technology transfer, management capabilities, improve the skill or ability to manage the equipment containing the charge of high technology and the development of science, which in turn can open up opportunities pitch greater work again. Negative aspect sought by all means to achieve a profit as much as possible through unnatural practices as smuggling taxes, controlling market with monopoly and in line with the development of globalization foreign investment wishes to remain grounded in order of values liberalization, carrying when later investment will be made so that the investment recipient country must make room for regulation that accommodates the interests of economy and trade liberalization.

In accordance with the above description of the legal aspects of a dominant position to maintain and regulate the balance of interests among the parties involved in the investment. Including other interests, which are the consumer, the environment and society at large. One major focus that emerged in studying in order to get clear about what the law means, then the efforts cannot be separated from the steps

14 Moh. Saleh, "Persaingan Usaha yang Sehat dalam Perspektif Perlindungan Konsumen”, Jurnal Media Hukum, Volume 14 No. 3 November 2007. Yogyakarta: Law Faculty, Muhammadiyah University, page 26. to identifying the law itself. ${ }^{15}$ The meaning of investment which starts from a premise that investment is a need, so it activity is recognized by a very complex business activity which have huge influence and impact both individual, group, social, economy and various effects, obligations, and responsibility, including the right that arise are always presented first. ${ }^{16}$

A partnerships model as stipulated in Government Regulation number 44 of 1997 , is the pattern of plasma core, sub-contracting, general trading, agency and franchising. Further details about the partnership model of which are a pattern of plasma core; sub-contract; general trade; agency and franchise. First, the pattern of Plasma core is a partnership of relationship between small businesses with a medium or large business, which includes medium or large businesses to act as the core and small businesses as a plasma. The company is carrying out development ranging from the provision of production inputs, technical guidance, and the marketing products.

This pattern has been implemented between large and medium-sized enterprises, for example by the farmers. Farmers in the plasma position, while a large and medium-sized enterprises as the core to provide guidance and development of agriculture, which in terms of: provision and preparation of agricultural land or plantations; provision of production facilities; the provision of technical assistance, business management and production; acquisition and other necessary assistance which is need to the efficiency and productivity of business.

Second, the Sub Contract pattern of partnerships between small businesses with a medium or large business, which includes small businesses producing components required by medium or large businesses as part of its production. The patterns of large or medium-sized sub-contract enterprises are expected to provide assistance to small business/small industry include: the opportunity to spend a portion of

\footnotetext{
15 Sigit Irianto, "Paradigma Filsafati dalam Mengkaji IImu Hukum", Jurnal Hukum, Volume XVII 2007 Special Edition, Semarang: Law Faculty, Sultan Agung Islamic University, page 47.

16 Sri Redjeki Hartono, op.cit, page 6.
} 
both the production or components; opportunities as possible to small businesses in obtaining raw materials are produced continuously with the amount and at a reasonable price; provide technical assistance or management of production; conducting the process of acquisition, mastery and improvement of the technology needed; business financing.

Third, the Patterns of General Trade are a partnerships between small businesses with a medium or large business that includes a medium or large businesses to promote the product of small businesses. In the end, this partnership model is expected to be mutually beneficial, mutually reinforce and support each other. Fourth, the pattern of relations agency include the partnership in small businesses which are given the exclusive right to promote their goods and services from medium or large business partners. A small business as an agent is a spearheading of the marketing of large or medium-sized businesses. This means that small businesses have a direct contact with the consumer, therefore the aspects of marketing management are an important things that must be mastered by the agent. A large or medium-sized businesses are obliged to provide these skills by increasing the professionalism of agents through training. The higher of sales techniques, more products that will be sold and the profits is not only enjoyed by the agents but also by a large or medium-sized businesses. There could also a downside, whereas the big business as the stronger burden or specific targets to be achieved. On the other hand, it is justifiable to successful marketing and spur the spirit of agent, but on the other hand it is the exploitation of small businesses and this should not happen, because of the ethical aspects of business may be a serious problem. Fifth, the Franchise Pattern is a partnership in which the franchisor gives the right to use licenses, trademarks and the company distribution channels to franchisees with management guidance assistance.

\section{Conclusion}

A partnerships made between big, medium and small industries implies cooperation between large businesses, medium to small industrial or domestic industry based on 3 (three) main principles that need each other, mutually reinforcing and mutually beneficial for parties enter into a contract of partnership in the form of coaching and development on as mandated by the Act 25 of 2007 and Government Regulation 44 of 1997. The patterns of partnership that can be done for the benefit of the partner parties is able to form models as stipulated in Government Regulation 44 of 1997, namely the plasma core pattern, sub-contracting, general trading, agency and franchise.

\section{References}

Agustine, Oly Viana. "Konstitusi Ekonomi menghadapi Masyarakat Ekonomi ASEAN (MEA) Year 2015". Jurnal Konstitusi, Vol. 11 Number 4, December 2014;

Artadi, Ibnu. "Dekonstruksi Pemahaman Penyelesaian Sengketa Bisnis (Ekonomi dan Keuangan) Beraspek Pidana melalui Prosedur Perdamaian: Menuju Proses Peradilan Pidana Rekonsiliatif". Jurnal Hukum Responsif, Vol. 1, No. 1 of 2011. Cirebon: Fakultas Hukum Univ. Sunan Gunung Jati;

Atmasasmita, Romli. "Tiga Paradigma Hukum dalam Pembangunan Nasional". Jurnal Hukum Prioris, Vol. 3 No. 1 of 2012. Jakarta: Law Faculty, Trisakti University,;

Budiman, Haris \& Suwari Akhmaddhian. "Implementasi Reformasi Birokrasi Bidang Perizinan Penanaman Modal di Kabupaten Kuningan", Jurnal Ilmu Hukum Unifikasi, Vol. 1, No. 1 October 2013. Kuningan: Law Faculty, Kuningan University;

Bureni, Yunus. "Moralitas Pembentukan Peraturan Daerah dalam Upaya Mencapai Keadilan Substantif". Jurnal Legislasi Indonesia, Vol. 10 No. 2 June 2013. Jakarta: Direktorat Jenderal Peraturan Perundang undangan Kementerian Hukum dan HAM RI.

Dayanto. "Rekonstruksi Paradigma Pembangunan Negara Hukum Indonesia Berbasis Pancasila”. Jurnal Dinamika Hukum, Vol. 13 No. 3 September 2013. Purwokerto: Jenderal Soedirman University; 
Hartono, Sri Redjeki. 2007. Orientasi Ke Arah Pengelolaan Investasi (Sebuah Landasan Pemikiran Awal). Bandar Lampung: Lampung University;

Irianto, Sigit. "Paradigma Filsafati dalam Mengkaji Ilmu Hukum". Jurnal Hukum, Vol. XVII special edition of 2007. Semarang: Law Faculty, Sultan Agung Islamic University Semarang;

Kristiana, Yudi. "Ketika Hukum tidak Lagi Otentik". Jurnal Hukum Supremasi, Vol. IV, No. 1 October 2010-March 2011. Jakarta: Pusat Studi Hukum Bisnis Law Faculty of Sahid University;

Nasution, Bahder Johan. "Kajian Filosofis tentang Konsep Keadilan dari Pemi-kiran Klasik sampai Pemikiran Modern". Jurnal Hukum Justisia, 89 May-August 2014 of XXIII edition;

Prentha, Bahria. "Filsafat Hukum dan Nilai-Nilai Pancasila". Jurnal Ilmiah Kebijakan Hukum, Vol. 5 No. 2 August 2011. Jakarta: Pusat Pengkajian dan Pengembangan Kebijakan Kementerian Hukum dan HAM RI;

Rahardjo, Satjipto. 2010. Ilmu Hukum. Bandung: Alumni;
Saleh, Moh. "Persaingan Usaha yang Sehat dalam Perspektif Perlindungan Konsu-men". Jurnal Media Hukum, Vol. 14 No. 3 November 2007. Yogyakarta: Law Faculty Muhammadiyah University;

Sutrisno, Endang. "Tracing the Performance of Law in Indonesia (A Perspective of Thomas Kuhn's "Normal Science". Journal of Law, Policy and Globalization, May, 2015. International Institute for Science, Techn-ology \& Education Accelerating Global Knowledge Creation and Sharing;

"Implementasi Pengelolaan Sumber Daya Pesisir Berbasis Pengelolaan Wilayah Pesisir Secara Terpadu untuk Kesejahteraan Nelayan (Studi di Perdesaan Nelayan Cangkol Kelurahan Lemahwungkuk Kecamatan Lemahwungkuk Kota Cirebon)". Jurnal Dinamika Hukum, Vol. 14, No.1 January 2014. Purwokerto: Jenderal Soedirman University

Widjojanto, Bambang. "Negara Hukum, Korupsi dan Hak Asasi Manusia: Suatu Kajian Awal”. Jurnal Hukum Prisoris, Vol. 3 No.1, 2012. Jakarta: Fakultas Hukum Trisakti; 